\title{
Downbound Spiral? Economic Grievances, Perceived Social Protection, and Political Distrust
}

\section{Atle Haugsgjerd ${ }^{\mathrm{a}}$ and Staffan Kumlin ${ }^{\mathrm{b}}$}

${ }^{a}$ Department of Political Science, University of Oslo, Oslo, Norway; Institute for Social Research, Oslo, Norway ${ }^{b}$ Department, of Political Science, University of Oslo, Oslo, Norway and Institute for Social Research, Oslo, Norway

Atle Haugsgjerd, Senior Research Fellow, Institute for Social Research, Oslo, Norway; Postal address: PO Box 3233 Elisenberg, NO-0208 Oslo, Norway; Telephone: +47 93058583; email: a.h.haugsgjerd@ samfunnsforskning.no

Staffan Kumlin, Professor, Department of Political Science, University of Oslo, Norway; Postal address: Boks 1097 Blindern, 0317 Oslo; Telephone: +47 22841113; email: staffan.kumlin@stv.uio.no 


\title{
Downbound Spiral? Economic Grievances, Perceived Social Protection, and Political Distrust
}

\author{
Momentous events in Western democracies have brought renewed attention to \\ how various aspects of government-controlled policy outputs and outcomes \\ affect citizens' trust in politics. Unlike most previous research this study uses \\ individual-level panel data to test the link between government performance \\ evaluations and political trust. Moreover, we gauge performance in more policy \\ areas than previous research including key aspects of government-controlled \\ social services as well as a wide range of economic risks. We find that \\ evaluations of government performance affect political trust but that the evidence \\ is stronger for evaluations of social protection than for economic risks. Crucially, \\ our analysis suggests that the relationship between performance evaluations and \\ distrust is reciprocal. The relationship may be described as a "downbound spiral" \\ where dissatisfied groups develop distrust, which in turn makes for a more \\ pessimistic interpretation of economic risks and welfare state performance.
}

Keywords: political trust; government performance; welfare state satisfaction; economic risks; causality 


\section{Introduction}

Although distrust in political elites and institutions has been researched for some five decades, the phenomenon has recently received unparalleled attention. All over Europe, distrust has fueled populist parties, and the dramatic events of 2016 — "Brexit" and the ascent of President Trump — are widely seen as indications of contempt for the "political establishment." These developments have generated increased attention to the causes of political distrust. Recently, much research has highlighted the importance of evaluations of policy outputs and outcomes (shorthand: government performance). In particular, poor macroeconomic performance and soaring unemployment rates have been identified as keys to understanding distrust in politics in the wake of the financial crisis (e.g. Friedrichsen and Zahn 2014; Kroknes, Jakobsen and Grønning 2015; Polavieja 2013; van Erkel and van der Meer 2016).

We make three contributions to this literature. First, we analyze perceptions of government performance more broadly than previous research. We go beyond the macroeconomic performance aspects and simultaneously analyze a multitude of perceptions of economic grievances as well as of social protection and public services. As for grievances, we take on board newer insights into the multitude of politically relevant economic risks (Hacker, Rehm and Schlesinger 2013). As for services/protection, we go beyond a small number of oft-used European Social Survey items (e.g. Kestilä-Kekkonen and Söderlund 2016; Kumlin 2007; Lühiste 2014) and consider a wider range of perceived welfare state performance aspects.

Secondly, individual-level panel data allow us to better test the causal validity of much previous cross-sectional research. Specifically, we run "fixed effects" models controlling for time-invariant confounders, as well as illuminate reciprocal relationships through "cross-lagged" panel models. Here, we build on the insight that political 
distrust is not merely an end result of malperformance: distrust might also serve as a cognitive heuristic shaping future interpretation of economic risks and social protection (Rudolph 2017). As we discuss in the concluding section, reciprocal effects together with current knowledge about negative biases in information flows and citizen reactions, imply that welfare state performance evaluations and political distrust may affect each other in a (mostly) negative "downbound spiral."

Thirdly, recent research has either focused on the US, or the crisis-ridden countries in Southern Europe after 2008 (e.g. Christmann and Torcal 2017; Ellinas and Lamprianou 2014). We have, by contrast, collected Norwegian primary individual-level panel data in 2014-15, as the country suddenly experienced a structural economic shift due to falling oil prices. These developments received major media and political attention and made issues related to economic risks and welfare state policies highly salient. We thus complement past research by investigating performance and political trust in a context of a less severe, but still significant, economic shift compared to the post-2008 crises in Southern Europe.

We next develop our contributions in light of three strands of research. One shows how assessments of public services and social protection are strongly associated with generalized political trust. This work, however, relies on restricted measurement of independent variables and cross-sectional data leaving unresolved questions of causality. A second literature demonstrates how economic grievances and risks affect attitudes. Work in this vein, however, emphasizes short-term implications of actual and feared job loss on specific policy preferences and protests, leaving aside questions about broader generalizations in terms of political distrust. The third section, finally, provides the idea of political trust as a heuristic in an emerging research program on 
consequences of distrust. Having discussed these bodies of work, we move on to the Norwegian context, then data and modeling strategy, and ultimately empirical results.

\section{Theory}

\section{Welfare state performance and political trust}

Already foundational work on political trust considered the possible importance of political and economic performance. David Easton (1975:449), for example, argued that the "evaluation of outputs and performance may help to generate, and probably at all times will help to sustain, confidence in authorities." In practice, however, the vast majority of empirical studies have examined macroeconomic performance while often ignoring other policy domains. Indeed, recent studies point to weak macroeconomic performance, and in particular surging unemployment rates, as one key to understanding contemporary distrust in politics (e.g. Friedrichsen and Zahn 2014; Kroknes, Jakobsen and Grønning 2015; Polavieja 2013; van Erkel and van der Meer 2016).

Important changes in the welfare state domain, however, long went largely unnoticed to the political trust literature. Current welfare state research often comes with the observation that mature welfare states struggle to finance their previous commitments to citizens (for an overview, see Hemerijck 2013). Key aspects of government-controlled outputs and outcomes are changing. Benefit generosity has slowly deteriorated (c.f. Allan and Scruggs 2004) while income and wealth inequalities — which partly reflect the redistributive capacities of welfare states — have increased (Brandolini and Smeeding 2008). There is also a "dualization" process where benefits and services remain reasonably stable for "insiders," but where growing groups are denied full access due to non-standard employment (Emmenegger et al. 2012). Welfare states, finally, are being "recalibrated" to address "new risks" (Bonoli 2005; Ferrera 
2008). There is a shift away from the classic goals of income security and equality for the benefit of "social investment" (Morel, Palier and Palme 2012), aimed at economic growth, and equality of "opportunity" rather than of "outcome."

Against this background, an emerging literature investigates the political consequences of outputs and outcomes in the welfare state domain. A key finding is that electoral punishment for welfare state change and dissatisfaction is weak and variable (e.g. Giger and Nelson 2011). A possible explanation is that the clinical distinction between incumbents and "politics" more generally is unusually difficult. On top of generic political-institutional conditions making it hard for citizens to attribute blame (complex coalitions, short incumbency periods, unclear government alternatives etc.) policymakers build blame-avoidance strategies into the design of welfare reform (e.g. Hood 2007; Pierson 1994; Weaver 1986). Dissatisfied citizens may therefore be extra prone to generalize to politicians and institutions more generally. A recent overview find support for this contention in existing research. Subjective assessments and personal experiences of services and benefits, as well as macro variables like income inequality and benefit generosity, are consistently associated with political trust in multivariate models (Kumlin and Haugsgjerd 2017).

But unresolved issues concerning causality and measurement remain. Previous research is almost exclusively based on cross-sectional data making associations open for several interpretations. We presently do not know if relationships are due to unmodeled confounders and/or reciprocal causation. This applies particularly for studies that predict political trust with subjective performance assessments. Indeed, few studies rely on individual level panel data, and the few existing panel studies do not study 
political trust but rather neighbouring concepts such as "democratic citizenship" (e.g. Watson 2015). ${ }^{1}$

As for measurement, most studies have been forced to rely on whatever performance assessments are offered by available data. In practice, for the many studies relying on the European Social Survey, this means founding conclusions on two items: performance in "health services" and "education" (e.g. Ellinas and Lamprianou 2014; Kestilä-Kekkonen and Söderlund 2016; Kumlin 2007; Lühiste 2014; Torcal 2017). Analysing these highly salient public services has been valuable but they capture only parts of the policy outputs and outcomes of mature welfare states. Importantly, they only remotely tap performance in areas most important to economically vulnerable citizens. We therefore broaden the menu of performance evaluations to include satisfaction with a wide range of public services, perceptions of living standard for vulnerable groups as well as evaluations of procedural fairness in the service delivery process.

\section{The political relevance of economic grievances}

A second research program addresses the impact of individual economic grievances, risks, and worries (shorthand: grievances) on political attitudes. While much older research has been skeptical about the explanatory power of economic self-interest (e.g. Sears and Funk 1991), such explanations have come to the forefront of political behavior research in the wake of the Great Recession. Particular attention has been given to whether big economic setbacks spur demand for social insurance and

1 But see Christmann and Torcal (2017) for a recent study of satisfaction with democracy using individual-level panel data. They do not, however, investigate effects of any welfare state related outcome. 
redistribution. Experts and pundits alike have often expected popular reactions to be 'both dramatic and consequential' (see Bermeo and Bartels 2014 for an overview), yet such prophecies have failed in a broad aggregate sense. Studies have found more stability than expected, and where attitudinal changes 'did occur, they were often of short duration' (Bermeo and Bartels 2014:8). This suggests, in the words of Margalit (2013:81),

... that while economic shocks can have a sizable effect on welfare preferences of individuals, the effect is probably not a reflection of a profound conversion in their political world view. Rather, the attitudinal change appears to reflect a more provisional response to an immediate and sometimes temporary need, and as such can be fairly short lived.

Importantly, these studies concern changes in policy preferences, and the study of citizens' dynamic economic experiences has rarely been extended to political trust (but see Finkel, Muller and Seligson 1989). However, economic risks, paired with negative developments of social protection for vulnerable groups, and with difficulties in managing pointed accountability, especially in the welfare state area, may also create general frustrations and distrust in the political system that go beyond short-lived and specific policy demand effects. Certainly, the combination of harsh austerity measures and a substantial drop in political trust in countries most severely affected by the Great Recession is consistent with this claim (Armingeon and Guthmann 2014).

Sources of economic risks, however, are not confined to the labour market. As Hacker et al (2013:44) argues, 'though job loss looms large in people's economic thinking ... insecurity is a reflection of multiple, intersecting risks. These extend beyond employment risks to include major economic losses driven by family, wealth and health changes.' Crucial aspects of government-controlled policy outputs and outcomes have in recent decades changed in response to such "new social risks" such as 
involuntary part time work, divorce, and child poverty that many welfare states previously failed to cover well. Most work on political trust, however, has ignored these new risks rooted outside the labour market. Recent work by Emmenegger, Marx and Schraff (2015), however, shows that not only unemployment, but other labour-market disadvantages such as involuntary part-time work, temporary employment and lowwage employment matter for citizens' trust in politics. They argue that their results testify to the political importance of the ongoing "dualization" process bifurcating insiders of the labour market with secure employment from outsiders on the fringes of the labour market (Rueda 2005). We extend this approach by broadening the range of economic risks further beyond unemployment to include risks driven by changes in health, family and financial standing.

\section{Political distrust as a heuristic for evaluating performance and grievances}

We know much more about the causes of political distrust than about its consequences. In the opening chapter of Handbook on Political Trust, Zmerli and van der Meer (2017:8) even observe that:

The empirical consequences of political trust are the biggest deficiency in the trust literature. We simply lack systematic information on how much low and declining levels of political trust should be of concern to representative democracy. In part, this major gap in the literature reflects data limitations - that is, the lack of experimental, longitudinal and, in particular, panel data [...] studies have predominantly assessed the correlates of high and low levels of trust at one point in time, and have thus been unable to separate cause from effect.

We help to fill this gap and thus join a small group of studies assessing effects of political trust on political behavior (Rooduijn, van der Brug and de Lange 2016; van Deth 2017). These studies are important, but consider mainly undesirable or protest- 
oriented reactions vis-a-vis or within democracy itself. We currently know less about the additional possibility that distrust works as a cognitive "heuristic," shaping substantive political information processing.

The notion of cognitive heuristics (or "shortcuts") entails that citizens are ordinarily unmotivated to collect and consider in-depth large amounts of issue-specific information. Citizens are "cognitive misers" who extract from limited information the implications of a more generalized orientation. To be sure, scholars have long demonstrated such processes, in particular for the impact of party identification and ideological orientations (Evans and Andersen 2004; Fuchs and Klingemann 1989; Zaller 1992). Now, ideology and partisanship are orientations with substantive meaning: they denote attachments to organizations with a cause or to ideological packages with policy content. By contrast, we examine if generalized overall distrust in politics and democracy functions as a cognitive lens through which citizens perceive and evaluate specific substantive aspects of politics, in this case social protection and economic grievances.

We draw inspiration from a series of studies on how trust affects specific policy preferences. These have been conducted almost exclusively in the US (Hetherington 1998; but see Trüdinger and Bollow 2011). As explained in Rudolph's overview (2017:200) they generally show that ' ...political trust operates as a simple heuristic or decision rule that enables people to more easily make evaluative judgements concerning government policies or actions.' In practice, this research is about proposed policy of (dis)trusted institutions. We shift the focus to judgements of government performance (i.e. policy outputs and outcomes). If such effects can be demonstrated then political distrust is not just an "end result" of economic grievances and poor social protection. Additionally, distrusting citizens are also prone to subsequently develop more negative 
views on performance. The implication is a "downbound spiral" in which

malperformance sets in motion a broader and more long-lived process than implied by past research: performance hurts trust, which in turn makes future performance evaluations more negative.

\section{Case description}

We use two-wave Norwegian panel data collected in spring/summer of 2014 (wave 1) and in spring of 2015 (wave 2) (Kumlin et al. 2017). Between the waves, Norway experienced a major, partly unexpected, and heavily politicized and debated economic shift due to falling oil prices. Of course, Norway has emerged in recent decades as something of Europe's economic counterfactual. Fuelled by oil- and gas revenues it has experienced an exceptional development, with unparalleled public savings, and employment-related and socio-economic indicators at levels enviable to other West European countries (Bengtsson et al. 2014). In the fall of 2014, however, the country's economic model and outlook was seriously challenged as oil prices began to fall from around 100 US dollars per barrel, and reaching a low point in January 2015 at less than 50. Meanwhile, exchange rates against the dollar and the euro grew and unemployment rates started a slow climb from low levels (especially in the southwestern regions where the economy is more oil dependent).

These developments received major media and political attention. They fed into a national narrative where most actors agreed on the need for economic adjustmentomstilling — although actors disagreed over what kind of adjustment, and just how serious the implications might be. Searches in media archives (using keywords related to oil prices, exchange rates, economic shift/decline/adjustment, and similar) suggest media attention to these problems grew and peaked roughly between December 2014 
and March 2015. By mid-January, as oil prices hit rock bottom, an extraordinary press conference followed a meeting between the prime minister, the finance minister, and the central bank governor, concerning the new situation in the Norwegian economy. Conservative prime minister Erna Solberg stated that

the development from mid-December with a continued fall in oil prices further underscores that the Norwegian economy will face significant challenges in the future as demand from the petroleum sector will decrease... That this activity will be lower is the new normal. It will require demanding adjustments from Norwegian companies and employees.

As ever in Norwegian politics, a prominent theme in media and political commentary addressed possible negative implications for Norway's generous and costly welfare state. Moreover, the fall in oil prices not only spurred concerns among commentators and political decision makers, but was also detrimental for the public's "economic mood". Figure 1 displays the aggregate consumer confidence index (CCI) in Norway 2013-2016 based on monthly national representative samples. The CCI measures the level of optimism that citizens have about the performance of the economy and it is based on five questions concerning citizens' expectations for their own as well as the country's economy, unemployment and their ability to save money in the next 12 months. Clearly, the events of 2014-15 fueled widespread economic concerns in the public and thus made issues related to economic grievances and social protection more salient.

FIGURE 1 ABOUT HERE 
Still, it is important not to exaggerate the seriousness of the Norwegian situation. In contrast to the crisis-ridden countries of Southern Europe, the context is best described as one where an economically exceptional polity discovers and debates more intensely than before just exactly how much things have now changed for the worse. As we have emphasized, the recent wave of research on government performance either comes from the US, or uses Southern Europe to identify effects of performance factors in the wake of the Great Recession (e.g. Christmann and Torcal 2017; Ellinas and Lamprianou 2014). Norway in 2014-15, by contrast, provides an opportunity to study political trust amidst a less dramatic, but still significant, performance setback. In the concluding section, we discuss the generalisability of our findings.

\section{Data, research design and measurements}

\section{Data and research design}

We use individual-level panel data collected by TNS Gallup and their standing webpanel. A total of 5420 respondents completed interviews in wave 1, and 52 percent of these (2847) completed interviews in wave $2 .^{2}$ The target population is the adult Norwegian population; aged 18-75 years resided in 61 strategically selected municipalities and/or city districts.

Our analysis proceeds in three steps. First, we take advantage of all the observations in our panel using the so-called between-estimator for panel data analyses. That means we regress the average value of the dependent variable on the average value of the predictors for each individual (Petersen 2004). These models are analogous to

\footnotetext{
${ }^{2}$ In addition, 2161 respondents were newly recruited in 2015 .
} 
much previous cross-sectional research and provides a benchmark for evaluating subsequent dynamic models.

We then proceed by estimating fixed effects models. These are more conservative than the between-estimator as they rely only on within-individual variation. Substantively, we regress individual changes in political trust on individual changes in predictors. By holding all time-invariant factors constant we control for potential endogeneity caused by any observed or unobserved time-invariant factors (Allison 2009; Andreß, Golsch and Schmidt 2013).

Finally, we estimate a number of cross-lagged panel models. These are dynamic structural equation models in which each variable at $t_{2}$ is simultaneously predicted by its previous value at $t_{1}$ as well as by other variables of interest at $t_{1}$. We use these models to compare the relative direction and magnitude of cross-lagged effects to give evidence regarding causal direction and strength (Finkel 1995). ${ }^{3}$

\section{Measurements}

We measure political trust by constructing an index out of two questions tapping trust in national political parties, and trust in the national Parliament, respectively. These two variables have approximately equal distributions, and time series data show that levels of trust in parliament and trust in parties follow each other closely over time (Torcal

\footnotetext{
${ }^{3} \mathrm{We}$ control for time-invariant unobservables and estimate cross-lagged effects in separate models. Trying to combine fixed effects with cross-lagged effects may lead to serious estimation problems including error terms that are correlated with predictors (Allison, Williams and Moral-Benito 2017). The most popular method for dealing with these issues is so-called dynamic panel models which rely on lagged variables as instruments (GSS). This approach, however, is not possible in a two-wave panel like ours.
} 
2017). ${ }^{4}$ The trust questions were assessed on a four-point scale running from "Great trust" to "No trust". Our index ranges from low trust (0) to high trust (3), and it is internally consistent in both two waves in our panel with Cronback's Alpha values at $0.77\left(\mathrm{t}_{1}\right)$ and $0.78\left(\mathrm{t}_{2}\right)$.

As for independent variables, our survey allows for unusually rich measurement of welfare state performance evaluations. ${ }^{5}$ We construct three different subjective performance measures. First, in order to replicate previous research we construct an index based on four questions measuring satisfaction with two highly salient and politically contentious institutions in most mature welfare states: schools and health care services. Similar questions have regularly been asked in European Social Survey and are frequently employed in research on political trust (Kestilä-Kekkonen and Söderlund 2016; Kumlin 2007; Lühiste 2014; Torcal 2017). Our index ranges from 'very dissatisfied' (1) to 'very satisfied' (5) with Cronback's alpha values at 0.56 in both waves. Second, we construct an index of a battery of questions measuring subjective performance satisfaction with 13 different public services spanning over a wide range of policy areas that all contribute to the traditional goals of welfare states, i.e. social security and equality. This encompassing index measures citizens' overall satisfaction with the welfare state. The index ranges from 'very dissatisfied' (1) to 'very satisfied' (5) with Cronback's alpha values at $0.77\left(\mathrm{t}_{1}\right)$ and $0.80\left(\mathrm{t}_{2}\right)$. Third, we follow Van

\footnotetext{
${ }^{4}$ We do not include a question measuring trust in government in our index as we wish to minimize the amount of variation in our measurement reflecting partisan sympathies. However, we have also constructed an index based on factor scores of trust on parliament, parties, government and municipal councils. We reach substantively the same conclusions when we use this measure as we do when we use our two-item index. See Table A5 in the appendix.

${ }^{5}$ See appendix for question wording, coding and descriptive statistics.
} 
Oorschot and Meuleman (2012) and utilize a set of questions concerning the perceived standard of living of seven different welfare target groups (e.g. pensioners, unemployed). These questions measure government's perceived ability to secure a basic level of welfare for its citizens. This index ranges from 'extremely bad living standard' (1) to 'extremely good living standard' (11) with Cronback's alpha values at $0.86\left(\mathrm{t}_{1}\right)$ and $0.88\left(\mathrm{t}_{2}\right)$. Finally, we construct an index measuring perceived procedural fairness based on three questions concerning whether citizens' feel they have been treated fairly by the welfare state institutions they themselves have used the last 12 months (c.f. Grimes 2017). This index ranges from 1 to 4 with Cronback's alpha values at 0.85 in both waves.

With regard to economic grievances we follow Margalit (2013) and use three different measures. First, we include a dichotomous measure of employment status capturing if respondents are currently unemployed. While this is a standard way of measuring economic grievances in the literature, it is somewhat problematic in a Scandinavian context as unemployment rates are comparatively low and the amount of individual-specific changes limited. ${ }^{6}$ Second, we include a measure of respondent's personal income. This item is grouped into nine categories and used as a continuous variable in the analyses. Third, we include an index capturing respondents' worries about personal future economic risks. Crucially, we include a broad range of risks covering not only labour market risks but also risks related to changes in health, family and financial standing (Hacker, Rehm and Schlesinger 2013). In our main analyses we use an additive index spanning all these sources of risks ranging from 0 to 6 . In

\footnotetext{
${ }^{6}$ Approximately two percent of our respondents are unemployed $\left(t_{1}=1,8 \%(96)\right.$ and, $t_{2}=2,0 \%$
} $(100))$. 
addition, we supplement with more specific analyses where we look at these items separately and comment when this adds to or nuances the information provided by the index. ${ }^{7}$ Finally, we control for whether citizens supported the party/parties in government $^{8}$, education, religiousness, immigrant background, age and gender. ${ }^{9}$

\section{Analyses}

\section{Comparing with previous research: cross-sectional analyses}

We start by presenting a number of cross-sectional regression models estimated with the between-estimator. These models are comparable to previous (cross-sectional) research, and they serve as our baseline for comparison with more refined dynamic analyses to come. The political trust index is regressed on three groups of independent variables capturing economic grievances, welfare state evaluations and standard sociodemographic and political controls. Due to issues of multi-collinearity we include the different welfare state evaluation variables in separate models. ${ }^{10}$

\section{TABLE 1 ABOUT HERE}

With some notable exceptions the results corroborate previous research. Starting with welfare state evaluations, we find that the effect of satisfaction with schools and

\footnotetext{
${ }^{7}$ Results are reported in the appendix.

${ }^{8}$ Because of an error in the data gathering process our party preference measure in both waves askes what party or list the respondent voted for in the 2013 National election.

${ }^{9}$ Control variables capturing stable individual traits are, of course, omitted from the fixed effects analyses.

${ }^{10}$ See Table A4 in the appendix for correlation matrix of explanatory variables.
} 
health care services is positive and significant. Yet we add substantial explanatory power by including additional measures of welfare state satisfaction. This is evident by both the variance explained by the different measures, and by the size of the coefficients. Interestingly, the coefficient for the encompassing service evaluation index is considerably larger than that of the school- and health service index used in most previous research.

Moving on to economic grievances, we find, as expected, that income is positively related to political trust. Our index of perceived economic risk also has the expected effect on political trust: The more risk the lower political trust. Additional analyses show that most of this correlation is due to peoples' perceived risk of poverty (coefficient: -.08; p-value: 0.01). Perceived risk of unemployment, on the other hand, is weak and non-significant at the five percent level (coefficient: -0.02; p-value: 0.08). ${ }^{11}$ We also see that the effect of being unemployed is insignificant. As discussed in the method section, this may be partly due to few respondents being unemployed in the sample. At the same time, these findings may suggest that economic risks originating outside the labour market are (at least) equally important as job-related worries for political trust.

Finally, our control for government support requires a brief comment. The coefficient is negative indicating that those supporting one of the two parties in government have lower trust than others. This is contradictory to the home-team

\footnotetext{
${ }^{11}$ See table A6 in the appendix.
} 
hypothesis supported by much previous research (e.g. Anderson et al. 2005), but due to the fact there was a right wing populist party in government. ${ }^{12}$

\section{A spurious relationship? Fixed effects panel models}

In the fixed effects analyses reported in Table 2 we control for all observed and unobserved time invariant factors. Let us see if solely within-subject variation in our predictors can explain individual specific changes in political trust.

\section{TABLE 2 ABOUT HERE}

As expected, overall we find fewer significant results when we only rely on within-subject variation. Still, three out of four measures of welfare state satisfaction have effects in the expected positive direction (satisfaction with schools and health care services, global performance evaluations, and procedural fairness). None of our three economic indicators, on the other hand, have significant effects in the expected direction when controlling for stable unobservables. In fact, people actually respond to increased personal income by becoming less trustful in politics. Interestingly, however, more specific analyses of our economic risk items show that changes in perceived risk of divorce have a negative effect on political trust (coefficient: -0.05 ; $p$-value: 0.01$).{ }^{13}$ Again, this seems to encourage conceptualization of economic risks that goes beyond the labour market.

\footnotetext{
${ }^{12}$ Running the model without this variable does not alter the results substantively. Neither does separating out those without any party preference.

${ }^{13}$ See Table A7 in the appendix.
} 
In sum, we find that effects of welfare state satisfaction greatly surpass those of economic grievances when controlling for time-invariant factors. Yet we should be cautious not to draw too strict conclusions about the relative strength of these groups of variables based on this material alone. It is well established that predictors such as education (at least in Scandinavia) (Hakhverdian and Mayne 2012) and government support (Anderson et al. 2005) build political trust. The non-significant effects of these predictors in the models may simply suggest that effects are underestimated because of limited within-subject variation.

\section{A downbound spiral? Cross-lagged panel models}

Fixed-effects models alleviate (though do not solve) endogeneity problems caused by omitted variables. Still, these models do not specify the temporal ordering of any causal relationship between two variables. So far we have simply assumed a particular direction of causation (that perceived government performance affects political trust). However, as we have discussed there are well-founded theoretical reasons to suspect that political trust not only is caused by our predictors of interest, but also works as a heuristic shaping such attitudes. To investigate this possibility we now turn to a number of cross-lagged panel models. These are illustrated in Figure 2 below.

\section{FIGURE 2 ABOUT HERE}

We start by discussing the dynamic relationship between political trust and welfare state evaluations presented in table 3 (below). The results indeed suggest that political trust is both a consequence and a cause of welfare state evaluations. First, we find that initial levels $\left(t_{1}\right)$ of welfare state evaluations affect changes $\left(t_{1}-t_{2}\right)$ in political 
trust. That is, people respond to low levels of welfare state evaluations by becoming less politically trustful. Again, the encompassing service evaluation index has the strongest effects of our different measures. That said, we find similar (though weaker) effects for the other satisfaction measures as well.

\section{TABLE 3 ABOUT HERE}

At the same time, we find that people respond to low levels of political trust by becoming more dissatisfied with welfare state services. This result supports the notion of trust as a heuristic. Again we find similar effects across our different welfare state satisfaction measures. Further analyses show that this consistency across different measures is not simply due to the fact that different aspects of dissatisfaction are correlated. Rather, all measures are significantly affected in a "seemingly unrelated regression" design where error terms are assumed to be correlated and standard error appropriately adjusted (c.f. Zellner 1962).

\section{TABLE 4 ABOUT HERE}

Turning to the relationship between political trust and economic grievances in table 4, we also find some support for the notion that economic grievances spur political distrust, though less consistently than we found for welfare state evaluations. This is consistent with the fixed effects results. Personal income at $t_{1}$ has a significant positive effect on changes in political trust. Again we find no effect for unemployment and the perceived risk index. 
Finally, we investigate if initial levels of political trust affect how people perceive their own personal economic situation. As expected, changes in personal income and employment status are not affected by initial levels of political trust. This is reassuring as both self-reported income and employment status refer to more objective circumstances making the room for interpretation based on trust smaller. In contrast, table 4 suggests that people respond to high initial levels of political trust by feeling less threatened by economic risks, and conversely, respond to low initial levels of political trust by feeling more insecure in their own economic situation. Apparently the relationship between perceived economic risks and political trust (revealed by our crosssectional analyses) is a one-way relationship going from trust to economic risk. This suggests political trust can serve as a heuristic affecting not only how people judge the functioning of the welfare state, but also their own personal economic situation.

\section{Conclusions}

Momentous events in Western democracies have brought renewed attention to how government-controlled policy outputs and outcomes affect citizens politically. We have provided improved evidence that individual-level evaluative aspects of such performance factors matter beyond changes in specific policy-related demand and protest (as suggested by some research in the wake of the financial crisis). More than this, performance evaluations appear to have broader consequences for generalized trust in democratic actors and institutions.

Going into specifics, our panel-analyses confirm past cross-sectional associations between welfare state related dissatisfaction and political trust: increases in dissatisfaction produces more distrust over time and initial dissatisfaction yields subsequent downward changes in trust. These analyses do not solve all issues of 
endogeneity and future research should investigate these relationships with other research designs - experimental and observational - in a critical appraisal of causal inferences. Yet, they provide much-needed improved causal evidence compared to previous research. Equally important, they underscore the need for detailed conceptualization and measurement. Taking a key example, there is more to welfare dissatisfaction effects than can be uncovered by the now familiar European Social Survey items on health care and education evaluations. Additionally, we also found some effects of economic grievances and perceived risks. But these were weaker and less consistent. Still, we find some evidence that general worries about personal economic problems matter more for political trust than can be captured by labour market events and worries.

Crucially, we also found a reciprocal relationship supporting the notion of political trust as a consequential cognitive heuristic. Lower initial levels of trust appear to trigger changes towards more negative views on the functioning of the welfare state, as well as more pessimistic views of one's own economic risks. This adds to the small literature on political and democratic consequences of distrust, in that the relationship may best be described as a reciprocal spiral where negative performance evaluations fuel distrust, which in turn makes for a more pessimistic interpretation of risks and social protection. Actually, this is yet an observation suggesting that performance effects go beyond short-lived changes in specific policy demand. Rather, grievances, welfare dissatisfaction, and political distrust appear to affect each other in a reciprocal spiral, where a central component is a generalized orientation towards politics and democracy writ large.

At least two major tasks await future research. First, we need similar analyses in other contexts. The expectations on such research are not obvious. On the one hand, the 
effects might be even stronger elsewhere given Norway's economic exceptionalism and because the economic downturn we studied was mild compared to, say, the financial crisis in Southern Europe. On the other hand, effects might be weaker elsewhere as Social democratic welfare states tend to generate higher expectations on performance and, above all, a greater political and discursive salience of welfare state issues. Thus, the very size and visibility of "social democratic welfare states" may make citizens particularly prone to blame the political system for malperformance. Finally, a solomonic possibility is that these mechanisms offset each other such that our results, more than anything, point to processes that are relatively typical for West European welfare states. Relatedly, much research on performance factors and political trust in the recent decade comes from severely crisis-ridden southern European contexts. Part of our rationale was to study performance-trust processes in a very different context experiencing a much less severe, but still non-negligible, downturn. Still, our conclusions fit well with those of recent research conducted elsewhere.

A second task for future research concerns the long-term nature of the reciprocal causal processes that connect performance evaluations and political trust. That process is unlikely to be a perpetuum mobile among a given group of individuals. At least without further stimulus the process should grow weaker over time. Determining more exactly how long it might keep on running — and what could stop or fuel it—requires more than two panel waves collected over a longer time span.

A related issue is provoked by the our gloomy title suggesting a "downbound spiral." One might wonder, however, if these findings could not be seen as evidence also for a potentially positive spiral, in which increasingly appreciated performance generates more political trust over time? While this issue is hardly settled we would argue that current research suggests that downbound spirals are now more likely than 
upward ones. Mature welfare states have over several decades become increasingly exposed to an increasing multitude of negative reform pressures. Most scholars would agree that these have grown more severe and some even treat them as "objective" problems (e.g. Vis and van Kersbergen 2013). An objectively severe situation, together with negative biases in political discourse and media reporting, may also explain why citizens currently seem to receive more negative than positive information about welfare state development (Goerres, Kumlin and Karlsen Forthcoming). Recent experimental work, moreover, suggests that citizens can process and react to information about welfare state performance and sustainability (e.g. Naumann 2017). However, they appear to be especially prone to react to negative narratives suggesting the welfare state is in trouble (Goerres, Karlsen and Kumlin 2018, first view ). Granted, there are experimental results suggesting that people are somewhat susceptible also to positive welfare state performance information (Kumlin and Stadelmann-Steffen 2014). Thus, whenever they receive such information it should positively enhance evaluations and thus start an upwards positive spiral. Still, the totality of current evidence would suggest that citizens are more likely to receive negative narratives suggesting the welfare state is in trouble, and are probably more prone to react to such negative information. Should these generalizations - together with the reciprocal model analyzed here- receive continued support then speaking about a "downbound spiral" in the relationship between welfare state performance evaluations and political trust would seem truly warranted. 


\section{References}

Allan, James P., and Lyle Scruggs. 2004. "Political Partisanship and Welfare State Reform in Advanced Industrial Societies." American Journal of Political Science 48(3):496-512.

Allison, Paul D. 2009. Fixed effects regression models: SAGE publications.

Allison, Paul D, Richard Williams, and Enrique Moral-Benito. 2017. "Maximum

Likelihood for Cross-Lagged Panel Models with Fixed Effects." Socius:

Sociological Research for a Dynamic World 3.

Anderson, Christopher J., André Blais, Shaun Bowler, Todd Donovan, and Ola

Listhaug. 2005. Losers' Consent: Elections and Democratic Legitimacy. Oxford:

Oxford University Press.

Andreß, Hans-Jürgen, Katrin Golsch, and Alexander W Schmidt. 2013. Applied panel data analysis for economic and social surveys. Berlin: Springer Verlag.

Armingeon, Klaus, and Kai Guthmann. 2014. "Democracy in crisis? The declining support for national democracy in European countries, 2007-2011." European Journal of Political Research 53(3):423-42.

Bengtsson, Åsa , Kasper Hansen, Ólafur P Harõarson, Hanne Marthe Narud, and Henrik Oscarsson. 2014. The Nordic Voter: Myths of Exceptionalism: ECPR Press.

Bermeo, Nancy, and Larry Bartels. 2014. Mass Politics in Tough Times: Opinions, Votes and Protest in the Great Recession. New York, NY: Oxford University Press.

Bonoli, Guiliano. 2005. "The Politics of New Social Policies: Providing Coverage against New Social Risks in Mature Welfare States." Policy and Politics 33(3):431-49.

Brandolini, Andrea, and Timothy M. Smeeding. 2008. "Inequality Patterns in Western Democracies: Cross-Country Differences and Changes over Time." Pp. 25-61 in Democracy, Inequality, and Representation, edited by Pablo Beramendi and Christopher J. Anderson. New York: Russel Sage Foundation.

Christmann, Pablo, and Mariano Torcal. 2017. "The political and economic causes of satisfaction with democracy in Spain - a twofold panel study." West European Politics 40(6):1241-66. 
Easton, David. 1975. "A Re-Assessment of the Concept of Political Support." British Journal of Political Science 5(4):435-57.

Ellinas, Antonis A., and Iasonas Lamprianou. 2014. "Political Trust In Extremis." Comparative Politics 46(2):231-50.

Emmenegger, Patrick, Silja Häusermann, Bruno Palier, and Martin Seeleib-Kaiser (Eds.). 2012. The Age of Dualization: The Changing Face of Inequality in Deindustrializing Societies. Oxford: Oxford University Press.

Emmenegger, Patrick, Paul Marx, and Dominik Schraff. 2015. "Labour market disadvantage, political orientations and voting: how adverse labour market experiences translate into electoral behaviour." Socio-Economic Review 13(2):189-213.

Evans, Geoffrey, and Robert Andersen. 2004. "Do issues decide? Partisan conditioning and perceptions of party issue positions across the electoral cycle." British Elections \& Parties Review 14(1):18-39.

Ferrera, Maurizio. 2008. "The European Welfare State: Golden Achievements, Silver Prospects." West European Politics 31(1-2):82 - 107.

Finkel, Steven E. 1995. Causal analysis with panel data. Thousand Oaks, CA: Sage.

Finkel, Steven E, Edward N Muller, and Mitchell A Seligson. 1989. "Economic crisis, incumbent performance and regime support: A comparison of longitudinal data from West Germany and Costa Rica." British Journal of Political Science 19(03):329-51.

Friedrichsen, Jana, and Philipp Zahn. 2014. "Political support in hard times: Do people care about national welfare?" European Journal of Political Economy 35(0):2337.

Fuchs, Dieter, and Hans-Dieter Klingemann. 1989. "The Left-Right Schema." Pp. 20334 in Continuities in Political Action. A Longitudinal Study of Political Orientations in Three Western Democracies, edited by M Kent Jennings and Jan W. van Deth. Berlin: Walter de Gruyter \& Co.

Giger, Nathalie, and Moira Nelson. 2011. "The electoral consequences of welfare state retrenchment: Blame avoidance or credit claiming in the era of permanent austerity?" European Journal of Political Research 50(1):1-23. 
Goerres, Achim, Rune Karlsen, and Staffan Kumlin. 2018, first view "What Makes People Worry about the Welfare State? A Three-Country Experiment." British Journal of Political Science:1-19.

Goerres, Achim, Staffan Kumlin, and Rune Karlsen. Forthcoming. "Pressure without pain: What politicians (don't) tell you about welfare state change." Journal of Social Policy.

Grimes, Marcia. 2017. "Procedural Fairness and Political Trust." Pp. 256-69 in Handbook on Political Trust, edited by Sonja Zmerli and T. W. G. Van der Meer. Cheltenham, UK: Edward Elgar Publishing.

Hacker, Jacob S, Philipp Rehm, and Mark Schlesinger. 2013. "The insecure American: Economic experiences, financial worries, and policy attitudes." Perspectives on Politics 11(01):23-49.

Hakhverdian, Armen, and Quinton Mayne. 2012. "Institutional Trust, Education, and Corruption: A Micro-Macro Interactive Approach." The Journal of Politics 74(03):739-50.

Hemerijck, Anton. 2013. Changing welfare states. Oxford: Oxford University Press. Hetherington, Marc J. 1998. "The Political Relevance of Political Trust." American Political Science Review 92(4):791-808.

Hood, Christopher. 2007. "What Happens When Transparancey Meets Blame Avoidance." Public Management Review 9(2):191-210.

Kestilä-Kekkonen, Elina , and Peter Söderlund. 2016. "Political Trust, Individual-level Characteristics and Institutional Performance: Evidence from Finland, 200413." Scandinavian Political Studies 39(2):138-60.

Kroknes, Veronica Fagerland, Tor Georg Jakobsen, and Lisa-Marie Grønning. 2015. "Economic performance and Political Trust: The impact of the Financial Crisis on European citizens." European Societies 17(5):700-23.

Kumlin, Staffan. 2007. "Overloaded or Undermined? European Welfare States in the Face of Performance Dissatisfaction." Pp. 80-116 in The Political Sociology of the Welfare State: Institutions, Social Cleavages, and Orientations, edited by Stefan Svallfors. Stanford: Stanford University Press.

Kumlin, Staffan, Audun Fladmoe, Rune Karlsen, Kari Steen-Johnsen, Dag Wollebæk, and Hanna Bugge. 2017. "Support for the affluent welfare state 
(SuppA). A Norwegian panel study on welfare state orientations, social capital, and local context." Oslo: Institute for Social Research.

Kumlin, Staffan, and Atle Haugsgjerd. 2017. "The welfare state and political trust: Bringing performance back in." Pp. 285-301 in Handbook on Political Trust, edited by Sonja Zmerli and Tom Van der Meer. Cheltenham, UK: Edward Elgar Publishing.

Kumlin, Staffan, and Isabelle Stadelmann-Steffen (Eds.). 2014. How Welfare States Shape the Democratic Public: Policy Feedback, Participation, Voting, and Attitudes. Cheltenham, UK: Edward Elgar Publishing.

Lühiste, Kadri. 2014. "Social Protection and Satisfaction with Democracy: a Multi-level Analysis." Political Studies 62(4):784-803.

Margalit, Yotam. 2013. "Explaining social policy preferences: Evidence from the Great Recession." American Political Science Review 107(01):80-103.

Morel, Nathalie, Bruno Palier, and Joakim Palme (Eds.). 2012. Towards a Social Investment Welfare State? Bristol: Policy Press.

Naumann, Elias. 2017. "Do Increasing Reform Pressures Change Welfare State Attitudes? An experimental study on population ageing, pension reform preferences, political knowledge, and ideology." Ageing and Society 37(2):26694.

Petersen, Trond. 2004. "Analyzing panel data: Fixed-and random-effects models." Pp. 331-45 in Handbook of data analysis, edited by Melissa Hardy and Alan Bryman. Thousand Oaks, CA: Sage.

Pierson, Paul. 1994. Dismantling the Welfare State? Cambridge: Cambridge University Press.

Polavieja, Javier. 2013. "Economic Crisis, Political Legitimacy and Social Cohesion." Pp. 256-78 in Economic Crisis, Quality of Work and Social Integration: The European Experience, edited by Duncan Gallie. Oxford: Oxford University Press.

Rooduijn, Matthijs, Wouter van der Brug, and Sarah L de Lange. 2016. "Expressing or fuelling discontent? The relationship between populist voting and political discontent." Electoral Studies 43:32-40. 
Rudolph, Thomas J. 2017. "Political trust as a heuristic." Pp. 197-211 in Handbook on Political Trust, edited by Sonja Zmerli and T. W. G. Van der Meer. Cheltenham, UK: Edward Elgar Publishing.

Rueda, David. 2005. "Insider-outsider politics in industrialized democracies: the challenge to social democratic parties." American Political Science Review 99(01):61-74.

Sears, David O, and Carolyn L Funk. 1991. "The role of self-interest in social and political attitudes." Advances in experimental social psychology 24:1-91.

Torcal, Mariano. 2017. "Political trust in Western and Southern Europe." Pp. 418-39 in Handbook on Political Trust, edited by Sonja Zmerli and T. W. G. Van der Meer. Cheltenham, UK: Edward Elgar Publishing.

Trüdinger, Eva-Maria, and Uwe Bollow. 2011. "Evaluations of Welfare State Reforms in Germany: Political Trust Makes (a Big) Difference." Pp. 187-212 in Political Trust: Why Context Matters., edited by Sonja Zmerli and Marc Hooghe. Colchester: ECPR Press.

van Deth, Jan W. 2017. "Compliance, trust and norms of citizenship." Pp. 212-27 in Handbook on Political Trust, edited by Sonja Zmerli and Tom van der Meer. Cheltenham, UK: Edward Elgar Publishing.

van Erkel, P. F. A., and T. W. G. van der Meer. 2016. "Macroeconomic performance, political trust and the Great Recession: A multilevel analysis of the effects of within-country fluctuations in macroeconomic performance on political trust in 15 EU countries, 1999-2011." European Journal of Political Research 55(1):177-97.

Van Oorschot, Wim, and Bart Meuleman. 2012. "Welfare performance and welfare support." Pp. 25-57 in Contested welfare states: Welfare attitudes in Europe and beyond, edited by Stefan Svallfors. Standford, California: Standfford University Press.

Vis, Barbara, and Kees van Kersbergen. 2013. "Towards an Open Functional Approach to Welfare State State Change: Pressures, Ideas, and Blame Avoidance." Public Administration 91(4):840-54

Watson, Sara. 2015. "Does Welfare Conditionality Reduce Democratic Participation?" Comparative Political Studies 48(5):645-86. 
Weaver, R. Kent. 1986. "The Politics of Blame Avoidance." Journal of Public Policy 6(4):371-98.

Zaller, John R. 1992. The Nature and Origins of Mass Opinion. Cambridge: Cambridge University Press.

Zellner, Arnold. 1962. "An efficient method of estimating seemingly unrelated regressions and tests for aggregation bias." Journal of the American statistical Association 57(298):348-68.

Zmerli, Sonja, and Tom van der Meer (Eds.). 2017. Handbook on Political Trust.

Cheltenham, UK: Edward Elgar Publishing. 


\section{Tables}

Table 1. Cross-sectional analyses of political trust (0-3), between estimator

\begin{tabular}{|c|c|c|c|c|}
\hline & Model 1 & Model 2 & Model 3 & Model 4 \\
\hline \multirow[t]{2}{*}{ Female $(0-1)$} & $0.076^{* *}$ & $0.084^{* *}$ & $0.106^{* *}$ & $0.077^{* *}$ \\
\hline & $(0.015)$ & $(0.015)$ & $(0.016)$ & $(0.016)$ \\
\hline \multirow[t]{2}{*}{ Age (15-92) } & -0.000 & 0.000 & $0.002^{* *}$ & -0.001 \\
\hline & $(0.000)$ & $(0.000)$ & $(0.001)$ & $(0.001)$ \\
\hline \multirow[t]{2}{*}{ Education (1-5) } & $0.053^{* *}$ & $0.049^{* *}$ & $0.056^{* *}$ & $0.057^{* *}$ \\
\hline & $(0.007)$ & $(0.007)$ & $(0.007)$ & $(0.007)$ \\
\hline \multirow[t]{2}{*}{ Government support $(0-1)$} & $-0.126^{* *}$ & $-0.115^{* *}$ & $-0.157^{* *}$ & $-0.114^{* *}$ \\
\hline & $(0.016)$ & $(0.016)$ & $(0.016)$ & $(0.017)$ \\
\hline \multirow[t]{2}{*}{ Religiousness (1-11) } & $0.013^{* *}$ & $0.012^{* *}$ & $0.014^{* *}$ & $0.015^{* *}$ \\
\hline & $(0.003)$ & $(0.003)$ & $(0.003)$ & $(0.003)$ \\
\hline \multirow[t]{2}{*}{ Norwegian ethnic background $(0-1)$} & $0.058^{* *}$ & $0.063^{* *}$ & $0.101^{* *}$ & $0.058^{* *}$ \\
\hline & $(0.019)$ & $(0.019)$ & $(0.019)$ & $(0.020)$ \\
\hline \multirow[t]{2}{*}{ Unemployed (0-1) } & 0.000 & 0.009 & 0.024 & 0.009 \\
\hline & $(0.058)$ & $(0.058)$ & $(0.059)$ & $(0.060)$ \\
\hline \multirow[t]{2}{*}{ Personal income (1-9) } & $0.012^{* * *}$ & $0.013^{* *}$ & $0.011^{* *}$ & $0.009^{*}$ \\
\hline & $(0.004)$ & $(0.004)$ & $(0.004)$ & $(0.005)$ \\
\hline \multirow[t]{2}{*}{ Economic risk index (0-6) } & $-0.063^{* *}$ & $-0.062^{* *}$ & $-0.061^{* * *}$ & $-0.052^{* *}$ \\
\hline & $(0.009)$ & $(0.009)$ & $(0.010)$ & $(0.010)$ \\
\hline \multirow[t]{2}{*}{ Satisfaction school and health services (1-5) } & $0.277^{* * *}$ & & & \\
\hline & $(0.014)$ & & & \\
\hline \multirow[t]{2}{*}{ Welfare satisfaction global (1-5) } & & $0.440^{* *}$ & & \\
\hline & & $(0.020)$ & & \\
\hline \multirow[t]{2}{*}{ Living standards global (1-11) } & & & $0.062^{* *}$ & \\
\hline & & & $(0.005)$ & \\
\hline \multirow[t]{2}{*}{ Procedural fairness (1-4) } & & & & $0.230^{* *}$ \\
\hline & & & & $(0.013)$ \\
\hline \multirow[t]{2}{*}{ Intercept } & $0.152^{*}$ & $-0.336^{* *}$ & $0.572^{* *}$ & $0.430^{* *}$ \\
\hline & $(0.064)$ & $(0.077)$ & $(0.062)$ & $(0.060)$ \\
\hline $\mathrm{R}^{2}$ & 0.108 & 0.122 & 0.075 & 0.103 \\
\hline Observations & 9012 & 9013 & 8995 & 7889 \\
\hline Individuals & 6629 & 6630 & 6621 & 6029 \\
\hline
\end{tabular}

Standard errors in parentheses

${ }^{+} p<0.10,{ }^{*} p<0.05,{ }^{* *} p<0.01$ 
Table 2. Fixed effects models of political trust (0-3)

\begin{tabular}{|c|c|c|c|c|}
\hline & Model 1 & Model 2 & Model 3 & Model 4 \\
\hline Education (1-5) & $\begin{array}{l}-0.009 \\
(0.024)\end{array}$ & $\begin{array}{c}-0.009 \\
(0.024)\end{array}$ & $\begin{array}{c}-0.010 \\
(0.024)\end{array}$ & $\begin{array}{c}-0.014 \\
(0.026)\end{array}$ \\
\hline Government support $(0-1)$ & $\begin{array}{c}0.044 \\
(0.048)\end{array}$ & $\begin{array}{c}0.046 \\
(0.048)\end{array}$ & $\begin{array}{c}0.046 \\
(0.048)\end{array}$ & $\begin{array}{c}0.041 \\
(0.052)\end{array}$ \\
\hline Religiousness (1-11) & $\begin{array}{c}0.013 \\
(0.008) \\
\end{array}$ & $\begin{array}{c}0.012 \\
(0.008) \\
\end{array}$ & $\begin{array}{c}0.011 \\
(0.008) \\
\end{array}$ & $\begin{array}{c}0.008 \\
(0.009) \\
\end{array}$ \\
\hline Unemployment $(0-1)$ & $\begin{array}{l}-0.104 \\
(0.079)\end{array}$ & $\begin{array}{l}-0.101 \\
(0.079)\end{array}$ & $\begin{array}{c}-0.103 \\
(0.081)\end{array}$ & $\begin{array}{l}-0.077 \\
(0.082)\end{array}$ \\
\hline Personal income (1-9) & $\begin{array}{l}-0.019^{+} \\
(0.011)\end{array}$ & $\begin{array}{l}-0.019^{+} \\
(0.011)\end{array}$ & $\begin{array}{c}-0.019^{+} \\
(0.011)\end{array}$ & $\begin{array}{l}-0.026^{*} \\
(0.013)\end{array}$ \\
\hline Economic risk index (0-6) & $\begin{array}{c}-0.001 \\
(0.013) \\
\end{array}$ & $\begin{array}{c}-0.002 \\
(0.014) \\
\end{array}$ & $\begin{array}{r}-0.000 \\
(0.013) \\
\end{array}$ & $\begin{array}{c}-0.004 \\
(0.015) \\
\end{array}$ \\
\hline Satisfaction school and health services (1-5) & $\begin{array}{l}0.046^{*} \\
(0.021)\end{array}$ & & & \\
\hline Welfare satisfaction global (1-5) & & $\begin{array}{l}0.073^{* *} \\
(0.028)\end{array}$ & & \\
\hline Living standards global (1-11) & & & $\begin{array}{c}0.006 \\
(0.009)\end{array}$ & \\
\hline Procedural fairness (1-4) & & & & $\begin{array}{c}0.050^{*} \\
(0.021)\end{array}$ \\
\hline Intercept & $\begin{array}{l}1.421^{* *} \\
(0.125)\end{array}$ & $\begin{array}{l}1.344^{* *} \\
(0.134)\end{array}$ & $\begin{array}{l}1.554^{* *} \\
(0.116)\end{array}$ & $\begin{array}{l}1.510^{* * *} \\
(0.128)\end{array}$ \\
\hline Observations & 5021 & 5021 & 5007 & 4348 \\
\hline Individuals & 2638 & 2638 & 2633 & 2488 \\
\hline
\end{tabular}

All models are estimated using individual fixed effects and also include a time/wave dummy. Entries are estimated coefficients with cluster-robust standard errors in parentheses.

${ }^{+} p<0.10,{ }^{*} p<0.05,{ }^{* *} p<0.01$ 
Table 3. Cross-lagged effects: political trust (0-3) and welfare state evaluations

\begin{tabular}{|c|c|c|c|c|}
\hline & $\begin{array}{l}\text { Satisfaction } \\
\text { school and } \\
\text { health services } \\
(1-4)\end{array}$ & $\begin{array}{l}\text { Welfare } \\
\text { s|atisfaction } \\
\text { global } \\
(1-5) \\
\end{array}$ & $\begin{array}{l}\text { Living standards } \\
\text { global } \\
(1-11)\end{array}$ & $\begin{array}{l}\text { Procedural } \\
\text { fairness } \\
(1-4)\end{array}$ \\
\hline \multicolumn{5}{|l|}{ Cross-lagged effects } \\
\hline Welfare state evaluation $t_{1} \rightarrow$ & $0.076 * *$ & $0.119 * *$ & $0.026 * *$ & $0.051 * *$ \\
\hline Political trust $t_{2}$ & $(0.018)$ & $(0.026)$ & $(0.007)$ & $(0.017)$ \\
\hline Political Trust $t_{1} \rightarrow$ & $0.072 * *$ & $0.065 * *$ & $0.086 *$ & $0.078 * *$ \\
\hline Welfare state evaluation $t_{2}$ & $(0.014)$ & $(0.010)$ & $(0.035)$ & $(0.019)$ \\
\hline \multicolumn{5}{|l|}{ Stability of variables } \\
\hline Political Trust $\mathrm{t}_{1} \rightarrow$ & $0.621 * *$ & $0.617 * *$ & $0.630 * *$ & $0.628 * *$ \\
\hline Political trust $\mathrm{t}_{2}$ & $(0.018)$ & $(0.015)$ & $(0.014)$ & $(0.017)$ \\
\hline Welfare state evaluation $\mathrm{t}_{1} \rightarrow$ & $0.583 * *$ & $0.581 * *$ & $0.641 * *$ & $0.458 * *$ \\
\hline Welfare state evaluation $\mathrm{t}_{2}$ & $(0.016)$ & $(0.018)$ & $(0.016)$ & $(0.020)$ \\
\hline Number of individuals & 2744 & 2744 & 2733 & 2138 \\
\hline
\end{tabular}

Standard errors in parentheses

$* \mathrm{p}<0.05, * * \mathrm{p}<0.01$

All models include controls for education, gender, age, government support, religiousness and ethnic background at $t_{1}$, as well as correlated error terms at $t_{2}$ 
Table 4. Cross-lagged effects: political trust (0-3) and economic grievances

\begin{tabular}{|c|c|c|c|}
\hline & $\begin{array}{l}\text { Economic } \\
\text { risk index } \\
(0-6)\end{array}$ & $\begin{array}{l}\text { Personal } \\
\text { Income } \\
(1-9)\end{array}$ & $\begin{array}{l}\text { Unemployment } \\
(0-1)\end{array}$ \\
\hline $\begin{array}{l}\text { Cross-lagged effects } \\
\text { Economic grievances } \mathrm{t}_{1} \rightarrow \\
\text { Political trust } \mathrm{t}_{2}\end{array}$ & $\begin{array}{l}-0.017 \\
(0.012)\end{array}$ & $\begin{array}{l}0.011^{*} \\
(0.006)\end{array}$ & $\begin{array}{l}0.063 \\
(0.065)\end{array}$ \\
\hline $\begin{array}{l}\text { Political trust } \mathrm{t}_{1} \rightarrow \\
\text { Economic grievances } \mathrm{t}_{2}\end{array}$ & $\begin{array}{l}-0.074 * * \\
(0.021) \\
\end{array}$ & $\begin{array}{l}0.020 \\
(0.028)\end{array}$ & $\begin{array}{l}-0.004 \\
(0.004)\end{array}$ \\
\hline $\begin{array}{l}\text { Stability of variables } \\
\text { Political trust } \mathrm{t}_{1} \rightarrow \\
\text { Political trust } \mathrm{t}_{2}\end{array}$ & $\begin{array}{l}0.637 * * \\
(0.015)\end{array}$ & $\begin{array}{l}0.630 * * \\
(0.015)\end{array}$ & $\begin{array}{l}0.638 * * \\
(0.014)\end{array}$ \\
\hline $\begin{array}{l}\text { Economic grievances } \mathrm{t}_{1} \rightarrow \\
\text { Economic grievances } \mathrm{t}_{2}\end{array}$ & $\begin{array}{l}0.556 * * \\
(0.017) \\
2649\end{array}$ & $\begin{array}{l}0.883 * * \\
(0.010) \\
2480\end{array}$ & $\begin{array}{l}0.460 * * \\
(0.017) \\
2740\end{array}$ \\
\hline $\begin{array}{l}\text { Number of individuals } \\
\text { Standard errors in parentheses } \\
+\mathrm{p}<0.10 * \mathrm{p}<0.05 * * \mathrm{p}<0.01\end{array}$ & 2649 & 2489 & 2749 \\
\hline
\end{tabular}


Figure 1. Consumer Confidence Index (CCI) in Norway, 2013-2016

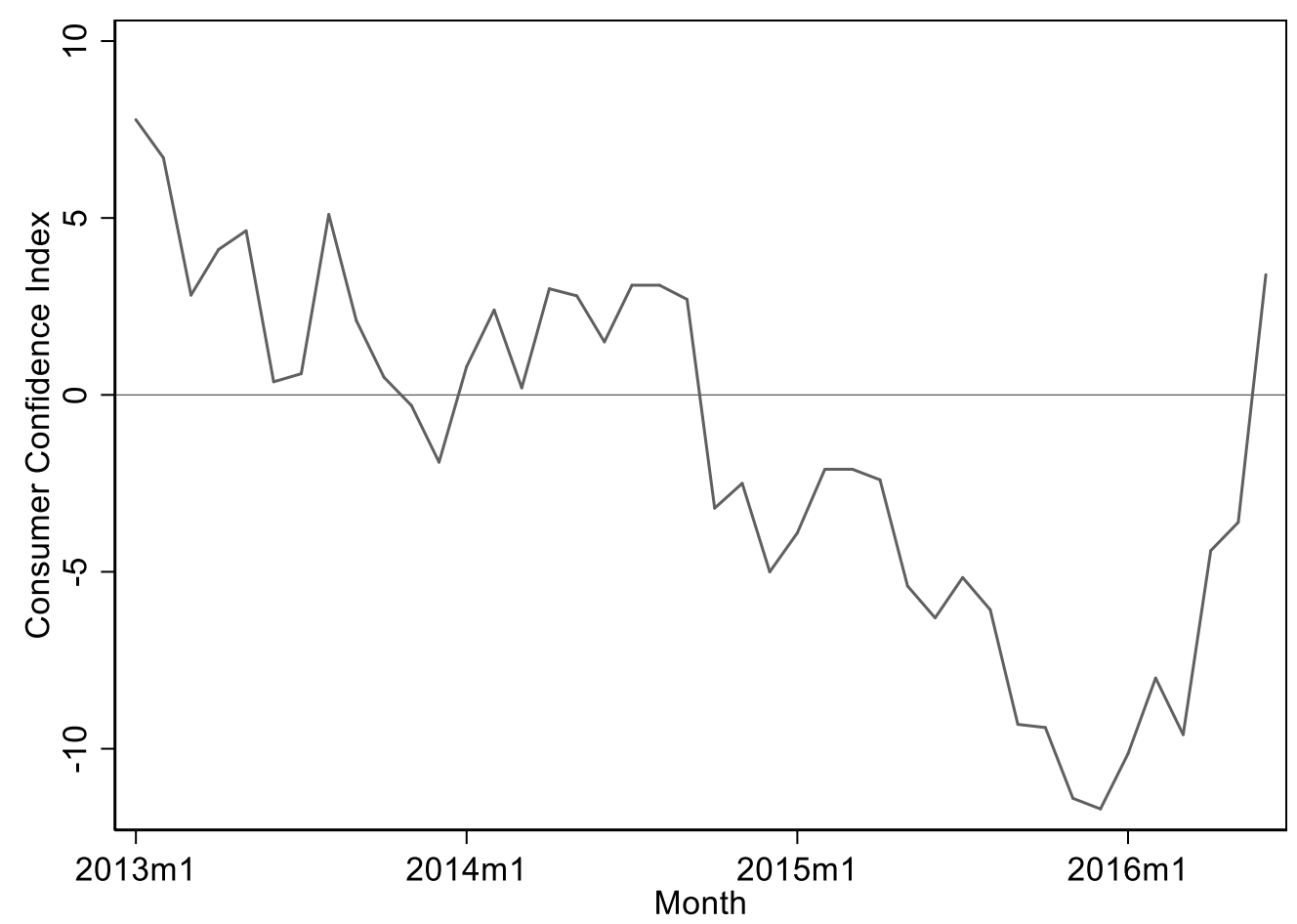

Note: A positive value indicates that the citizens are optimistic about the future economic situation; a negative value indicates pessimism. 
Figure 2. Two-wave cross-lagged panel models of political trust

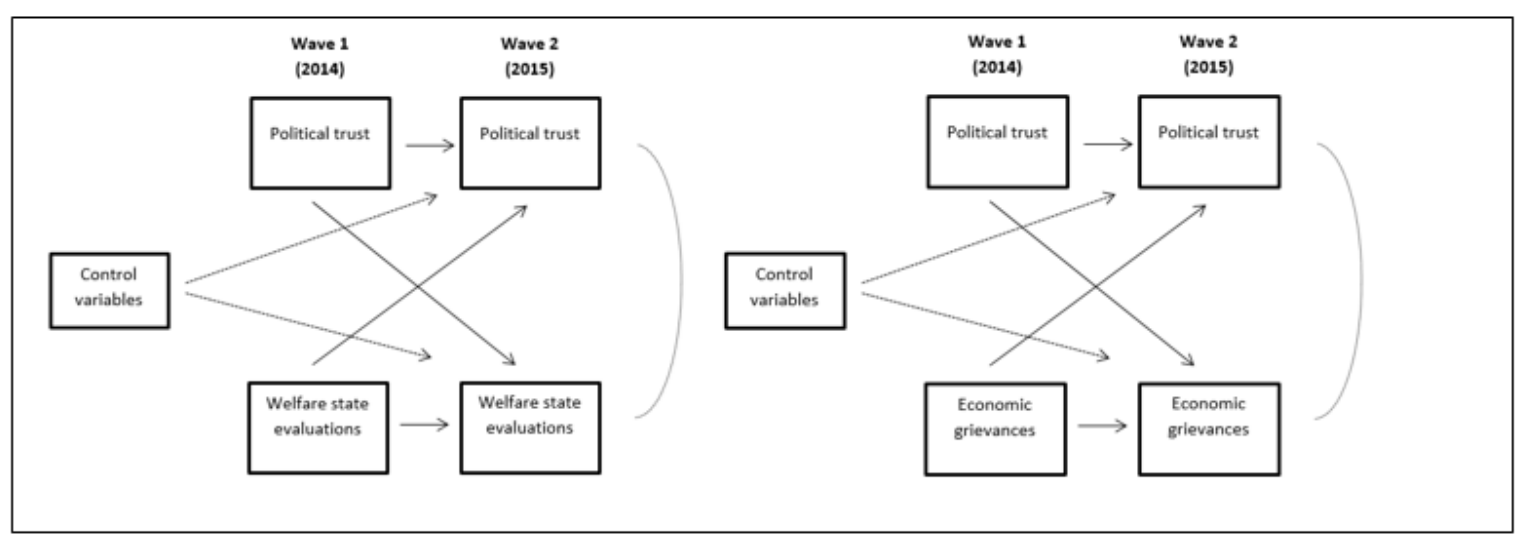




\section{APPENDIX}

A1. Question wording and variable coding

A2. Descriptive statistics: Cross-sectional

A3. Descriptive statistics: Within-subject variation

A4. Correlation matrix of explanatory variables

A5. Fixed effects models of political trust with alternative dependent variable

A6. Cross sectional models of political trust with separate economic risks items

A7. Fixed effects models of political trust with separate economic risks items 


\section{A1. Question wording and variable coding}

Political trust: The index is based on the following two questions: 'Various organizations and institutions are listed below. How much trust do you have in each of these?' (A) 'The Parliament' (B) 'The political parties'; (1) 'No trust' (2) 'Not very much trust' (3) 'Quite a lot of trust' (4) 'Great trust'

Age: Measured continuously in years

Education level: (1) 'Primary education (up to 10-year primary school, 7-year primary school or similar)' (2) 'Secondary education (general education, technical college or other)' (3) 'Professional training after secondary school or vocational school' (4) 'University/college education bachelor level/cand. Mag. or lower' (5)

'University/college education, Master's degree or higher'

Gender: (1) 'Male' (2) 'Female'

Norwegian ethnic background: 'Which country were you born in?' (1) 'Norwegian' (0) 'Other countries'

Religiousness: 'Regardless of whether you belong to a particular religion or not, how religious would you say you are?' (0) 'Not at all religious' (10) 'Very religious'

Government support: 'What party or list did you vote for in the 2013 National election?' (1) 'The Conservatives (Høyre)' or 'Progress Party (Fremskrittspartiet)' (0) 'All other parties'

Unemployment: 'What is your main source of livelihood? (1) ' Currently unemployed/unemployment benefits' (0) 'Other sources'

Personal income: 'Approximately what is your personal gross income (before taxes and deduction)?' (1) 'Below 200.000 kroner' (2) ‘200.000 - 299.999 kroner' (3) ‘300.000-399.000 kroner' (4) ‘400.000 - 499.999 kroner’ (5) ‘500.000 - 599.999 kroner'(6) ‘600.000 - 699.999 kroner' (7) ‘700-000-799.999 kroner' (8) ‘800.000 999.999 kroner' (9) ‘1.000.000 kroner or more’

Subjective economic risk: The index is based on the following six questions: 'Please tell me how likely you think it is that during the next 12 months you will ...' (A) 'Be unemployed and looking for work for at least four consecutive weeks' (B) 'Have to spend less time in paid work than you would like, because you have to take care of family members or relatives' (C) 'Be on sick leave for at least four consecutive weeks' (D) 'Become divorced or separated from your partner' (E) 'Not have enough money to cover your household necessities during some periods' ( $F)$ 'Be receiving disability benefits'; (1) 'Not at all likely' (2) 'Not very likely' (3) 'Likely' (4) 'Very likely'

Perceived living standards of welfare groups: The index is based on the following seven questions: 'What do you think overall about the standard of living for each of these different groups in Norway?' (A) 'Pensioners' (B) 'Unemployed' (C) 'Sick leave recipients' (D) 'Families with children' (E)' Single providers' (F) 'Disability benefit 
recipients' (G) 'Social welfare recipients'; (0) 'Extremely bad living standard' (10) 'Extremely good living standard'

Perceived procedural fairness: The index is based on the following three questions: 'If you now continue to think about those services you have used yourself during the past 12 months, to what degree would you say the following statements fit your own experience?' (A) 'Employees have worked quickly and efficiently' (B) 'I have received the service and help I am entitled to' (C) 'Employees have been helpful and listened to what I have had to say'; (1) 'Fits very poorly' (2) 'Fits rather poorly' (3) 'Fits your rather well' (4) 'Fits very well'

Satisfaction school and health services: The index is based on the following four questions: 'How satisfied or dissatisfied are you with the following services in your municipality/county?' (A) 'General practitioner (doctor)' (B) 'Emergency room/Casualty' (C)

'Municipal primary school' (D) 'Secondary school'; (1) 'Very dissatisfied' (2) Rather dissatisfied' (3) 'Neither satisfied nor dissatisfied (4) 'Rather satisfied' (5) 'Very satisfied'

Welfare satisfaction global: The index is based on the following thirteen questions: 'How satisfied or dissatisfied are you with the following services in your municipality/county?' (A) 'General practitioner (doctor)' (B) 'Emergency room/Casualty' (C) 'Municipal nursing home or retirement home' (D) 'Home care or home nursing care' (E) 'Norwegian Labour and Welfare Service (NAV)' (F) 'Municipal kindergarten' $(\mathrm{G})$ 'Municipal primary school' (H) 'Afterschool program' (I) 'Public health Centre' (J) 'Specialist Health Care Services' (K) 'Secondary school' (L) 'Higher education' (M) 'Rehabilitation Centre'; (1) 'Very dissatisfied' (2) Rather dissatisfied' (3) 'Neither satisfied nor dissatisfied (4) 'Rather satisfied' (5) 'Very satisfied' 
A2. Descriptive statistics: Cross-sectional

\begin{tabular}{lccccc}
\hline Variable & Obs. & Mean & Std. Dev. & Min & Max \\
\hline Political Trust $\mathrm{t}_{1}$ & 5286 & 1.52 & 0.63 & 0 & 3 \\
Political Trust $\mathrm{t}_{2}$ & 4921 & 1.50 & 0.63 & 0 & 3 \\
Satisfaction with school and health services $\mathrm{t}_{1}$ & 5411 & 3.52 & 0.53 & 1 & 5 \\
Satisfaction with school and health services $\mathrm{t}_{2}$ & 4998 & 3.57 & 0.54 & 1 & 5 \\
Welfare satisfaction global $\mathrm{t}_{1}$ & 5413 & 3.28 & 0.37 & 1 & 5 \\
Welfare satisfaction global $\mathrm{t}_{2}$ & 4998 & 3.31 & 0.39 & 1 & 5 \\
Living standards global $\mathrm{t}_{1}$ & 5391 & 6.19 & 1.44 & 1 & 11 \\
Living standards global $\mathrm{t}_{2}$ & 4989 & 5.97 & 1.48 & 1 & 11 \\
Procedural fairness $\mathrm{t}_{1}$ & 4698 & 3.06 & 0.64 & 1 & 4 \\
Procedural fairness $\mathrm{t}_{2}$ & 4354 & 3.15 & 0.62 & 1 & 4 \\
Economic risk index $\mathrm{t}_{1}$ & 5292 & 0.44 & 0.85 & 0 & 6 \\
Economic risk index $\mathrm{t}_{2}$ & 4901 & 0.40 & 0.82 & 0 & 6 \\
Personal income $\mathrm{t}_{1}$ & 4993 & 3.98 & 2.03 & 1 & 9 \\
Personal income $\mathrm{t}_{2}$ & 4590 & 4.11 & 1.97 & 1 & 9 \\
Unemployment $\mathrm{t}_{1}$ & 5304 & 0.02 & 0.13 & 0 & 1 \\
Unemployment $\mathrm{t}_{2}$ & 5008 & 0.02 & 0.14 & 0 & 1 \\
Government support $\mathrm{t}_{1}$ & 5410 & 0.32 & 0.47 & 0 & 1 \\
Government support $\mathrm{t}_{2}$ & 5410 & 0.32 & 0.47 & 0 & 1 \\
Education $\mathrm{t}_{1}$ & 5420 & 3.52 & 1.18 & 1 & 5 \\
Education $\mathrm{t}_{2}$ & 5008 & 3.56 & 1.18 & 1 & 5 \\
Age $\mathrm{t}_{1}$ & 5420 & 48.11 & 15.51 & 16 & 88 \\
Age $\mathrm{t}_{2}$ & 5007 & 51.81 & 15.69 & 15 & 92 \\
Female $\mathrm{t}_{1}$ & 5420 & 1.52 & 0.50 & 1 & 2 \\
Female $\mathrm{t}_{2}$ & 5008 & 1.53 & 0.50 & 1 & 2 \\
Religiousness $\mathrm{t}_{1}$ & 5326 & 4.13 & 2.89 & 1 & 11 \\
Religiousness $\mathrm{t}_{2}$ & 4946 & 4.15 & 2.82 & 1 & 11 \\
Norwegian ethnic background $\mathrm{t}_{1}$ & 5420 & 0.75 & 0.43 & 0 & 1 \\
Norwegian ethnic background $\mathrm{t}_{2}$ & 5008 & 0.87 & 0.33 & 0 & 1 \\
\hline & & & & & \\
\hline & & & & &
\end{tabular}


A3. Descriptive statistics: Within-subject variation

Variable Within percent

Political Trust

65,54

Satisfaction with school and health services

57,73

Welfare satisfaction global

Living standards global

51,59

Procedural fairness

67,59

Economic risk index

79,51

Personal income

75,49

Unemployment

97,94

Government support

95,50

Education

89,79

Religiousness

66,29

The within percent indicate the stability of each variable, that is, the percentage of respondents that did not change their score across waves 
A4. Correlation matrix of explanatory variables (pooled data)

\begin{tabular}{|c|c|c|c|c|c|c|}
\hline Satisfaction & Welfare & Living & Procedural & Economic & Personal & Unemployment \\
\hline with school & satisfaction & standards & fairness & risk index & income & \\
\hline and health & global & global & & & & \\
\hline
\end{tabular}

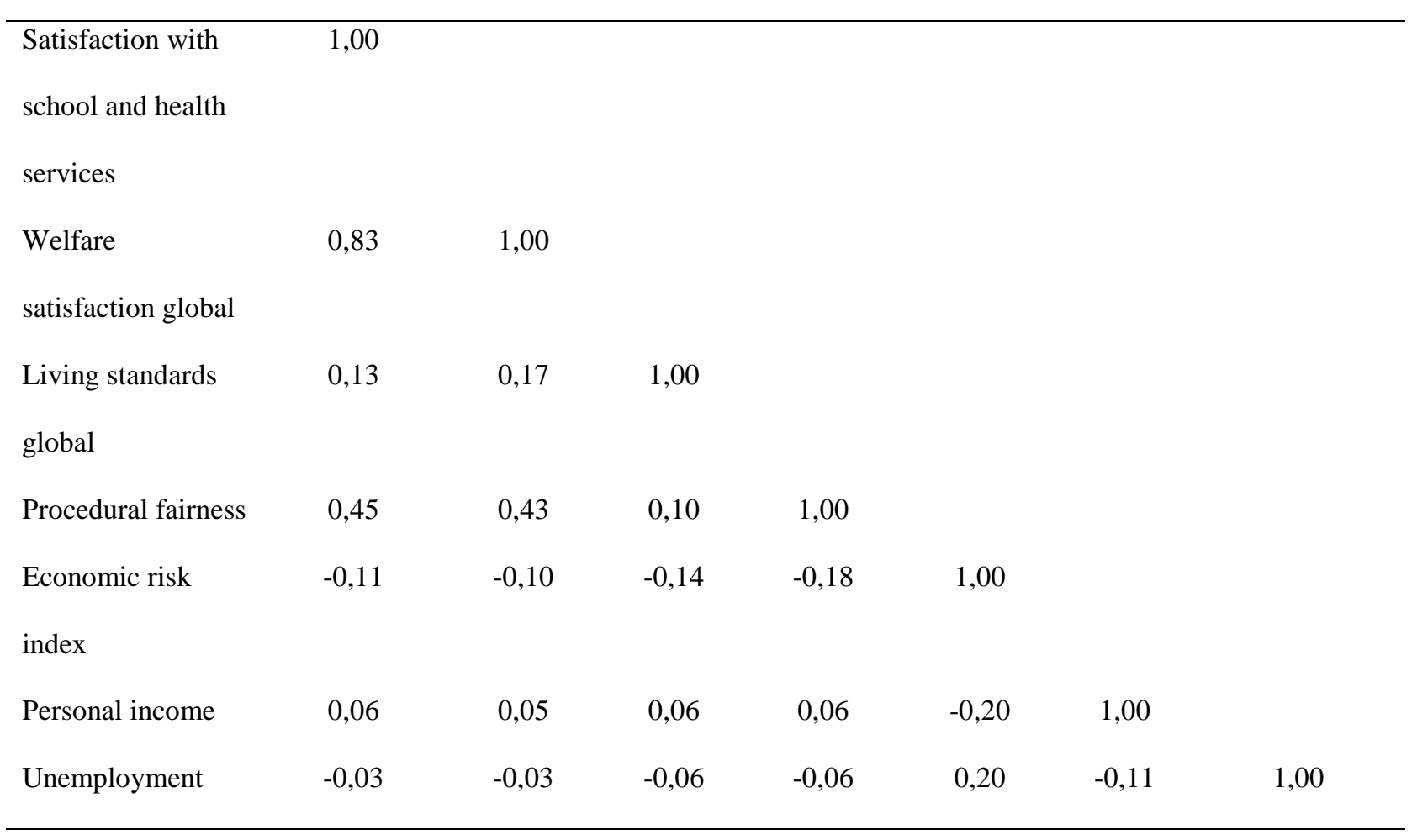


A5. Fixed effects models of political trust with alternative dependent variable

\begin{tabular}{|c|c|c|c|c|}
\hline & Model 1 & Model 2 & Model 3 & Model 4 \\
\hline Education (1-5) & $\begin{array}{c}0.000 \\
(0.036)\end{array}$ & $\begin{array}{c}-0.000 \\
(0.036)\end{array}$ & $\begin{array}{c}-0.001 \\
(0.036)\end{array}$ & $\begin{array}{c}-0.027 \\
(0.037)\end{array}$ \\
\hline Government support (0-1) & $\begin{array}{c}0.093 \\
(0.070)\end{array}$ & $\begin{array}{c}0.096 \\
(0.070)\end{array}$ & $\begin{array}{c}0.096 \\
(0.069)\end{array}$ & $\begin{array}{c}0.061 \\
(0.073)\end{array}$ \\
\hline Religiousness (1-11) & $\begin{array}{c}0.019 \\
(0.011)\end{array}$ & $\begin{array}{c}0.018 \\
(0.011)\end{array}$ & $\begin{array}{c}0.016 \\
(0.011)\end{array}$ & $\begin{array}{c}0.011 \\
(0.012)\end{array}$ \\
\hline Unemployment $(0-1)$ & $\begin{array}{l}-0.146 \\
(0.099)\end{array}$ & $\begin{array}{l}-0.140 \\
(0.098)\end{array}$ & $\begin{array}{l}-0.145 \\
(0.099)\end{array}$ & $\begin{array}{l}-0.157 \\
(0.102)\end{array}$ \\
\hline Personal income (1-9) & $\begin{array}{c}-0.023 \\
(0.016)\end{array}$ & $\begin{array}{l}-0.022 \\
(0.016)\end{array}$ & $\begin{array}{c}-0.022 \\
(0.016)\end{array}$ & $\begin{array}{c}-0.037^{+} \\
(0.019)\end{array}$ \\
\hline Economic risk index $(0-6)$ & $\begin{array}{c}-0.013 \\
(0.019)\end{array}$ & $\begin{array}{l}-0.015 \\
(0.019)\end{array}$ & $\begin{array}{l}-0.013 \\
(0.019)\end{array}$ & $\begin{array}{l}-0.010 \\
(0.021)\end{array}$ \\
\hline Satisfaction school and health services (1-5) & $\begin{array}{l}0.089^{* *} \\
(0.030)\end{array}$ & & & \\
\hline Welfare satisfaction global (1-5) & & $\begin{array}{l}0.127^{* *} \\
(0.039)\end{array}$ & & \\
\hline Living standards global (1-11) & & & $\begin{array}{c}0.008 \\
(0.013)\end{array}$ & \\
\hline Procedural fairness (1-4) & & & & $\begin{array}{c}0.075^{*} \\
(0.030)\end{array}$ \\
\hline Intercept & $\begin{array}{l}2.053^{* *} \\
(0.184)\end{array}$ & $\begin{array}{l}1.951^{* *} \\
(0.192)\end{array}$ & $\begin{array}{l}2.327^{* *} \\
(0.173)\end{array}$ & $\begin{array}{l}2.350^{* *} \\
(0.182)\end{array}$ \\
\hline Observations & 4747 & 4747 & 4733 & 4117 \\
\hline Individuals & 2572 & 2572 & 2566 & 2419 \\
\hline
\end{tabular}

All models are estimated using individual fixed effects and also include a time/wave dummy. Entries are estimated coefficients with cluster-robust standard errors in parentheses.

${ }^{+} p<0.10,{ }^{*} p<0.05,{ }^{* *} p<0.01$ 
A6. Cross sectional models of political trust with separate economic risks items, between- estimator

\begin{tabular}{|c|c|}
\hline & Model 1 \\
\hline Female (0-1) & $\begin{array}{l}0.081^{* *} \\
(0.015)\end{array}$ \\
\hline Age (15-92) & $\begin{array}{c}-0.000 \\
(0.001)\end{array}$ \\
\hline Education (1-5) & $\begin{array}{l}0.048^{* *} \\
(0.007)\end{array}$ \\
\hline Government support (0-1) & $\begin{array}{c}-0.119^{* *} \\
(0.016)\end{array}$ \\
\hline Religiousness (1-11) & $\begin{array}{l}0.011^{* *} \\
(0.003)\end{array}$ \\
\hline Norwegian ethnic background $(0-1)$ & $\begin{array}{l}0.064^{* *} \\
(0.019)\end{array}$ \\
\hline Unemployed (0-1) & $\begin{array}{l}-0.041 \\
(0.058)\end{array}$ \\
\hline Personal income (1-9) & $\begin{array}{l}0.015^{* *} \\
(0.004)\end{array}$ \\
\hline Welfare satisfaction global (1-5) & $\begin{array}{l}0.437^{* *} \\
(0.020)\end{array}$ \\
\hline Risk of unemployed (1-4) & $\begin{array}{c}0.020^{+} \\
(0.011)\end{array}$ \\
\hline Risk of family obligations (1-4) & $\begin{array}{c}0.004 \\
(0.012)\end{array}$ \\
\hline Risk of sick leave (1-4) & $\begin{array}{l}-0.016 \\
(0.012)\end{array}$ \\
\hline Risk of divorce (1-4) & $\begin{array}{c}-0.028^{+} \\
(0.015)\end{array}$ \\
\hline Risk of poverty (1-4) & $\begin{array}{c}-0.081^{* *} \\
(0.012)\end{array}$ \\
\hline Risk of disability benefits (1-4) & $\begin{array}{c}-0.014 \\
(0.011) \\
\end{array}$ \\
\hline Intercept & $\begin{array}{l}-0.065 \\
(0.094) \\
\end{array}$ \\
\hline $\begin{array}{l}\text { Observations } \\
\text { Individuals }\end{array}$ & $\begin{array}{l}9013 \\
6630\end{array}$ \\
\hline
\end{tabular}

Standard errors in parentheses

${ }^{+} p<0.10,{ }^{*} p<0.05,{ }^{* *} p<0.01$ 
A7. Fixed effects models of political trust with separate subjective economic risks items

\begin{tabular}{lc}
\hline & Model 1 \\
\hline Education (1-5) & -0.008 \\
& $(0.024)$ \\
Government support (0-1) & 0.039 \\
& $(0.048)$ \\
Religiousness (1-11) & 0.012 \\
& $(0.008)$ \\
\hline Unemployment (0-1) & -0.107 \\
& $(0.079)$ \\
Personal income (1-9) & $-0.019^{+}$ \\
& $(0.011)$ \\
Welfare satisfaction global (1-5) & $0.074^{* *}$ \\
& $(0.028)$ \\
\hline Risk of unemployed (1-4) & -0.017 \\
& $(0.017)$ \\
Risk of family obligations (1-4) & 0.009 \\
& $(0.016)$ \\
Risk of sick leave (1-4) & 0.011 \\
Risk of divorce (1-4) & $(0.015)$ \\
Risk of poverty (1-4) & $-0.050^{*}$ \\
Risk of disability benefits (1-4) & $(0.020)$ \\
& 0.013 \\
Intercept & $(0.019)$ \\
& $0.031^{+}$ \\
Observations & $(0.018)$ \\
\hline & $1.245^{* *}$ \\
& $(0.162)$ \\
\hline & 5021 \\
& 2638 \\
\hline & \\
&
\end{tabular}

The model is estimated using individual fixed effects and also includes a time/wave dummy. Entries are estimated coefficients with cluster-robust standard errors in parentheses.

${ }^{+} p<0.10,{ }^{*} p<0.05,{ }^{* *} p<0.01$ 